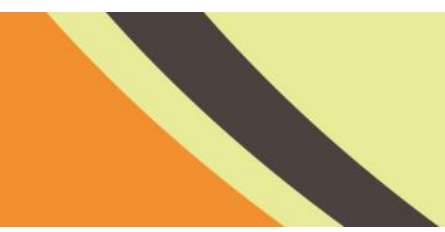

\title{
The Use of Fish Waste Based Organic Fertilizer to Improve the Growth of Balinese Red Rice (Oryza Sativa L Cv. Barak Cenana)
}

\author{
I Dewa Gede Cahyadi Kusuma ${ }^{1}$, Ni Luh Suriani ${ }^{2}$, Yan Ramona ${ }^{3}$ \\ ${ }^{1,2,3}$ Biology Department, Udayana University, Bukit-Jimbaran, Badung, Bali, Indonesia
}

\section{ARTICLE INFO}

Article History:

Received: 11 June 2021

Final Revision: 10 August 2021

Accepted: 17 August 2021

Online Publication: 30 August 2021

\section{KEYWORDS}

Seed soaking, PGPR, glasshouse, organic fertilizer, Balinese Red Rice

\section{CORRESPONDING AUTHOR}

*E-mail: niluhsurianisuriani@yahoo.com

\section{A B S T R A C T}

In recent years, wastes have been reprocessed into useful products, such as organic fertilizer. The application of organic fertilizers in farming practices can produce agricultural products that are safe for human health and the environment. The objective of this study was to investigate the effect of liquid organic fertilizer made from fish waste on the growth of Bali red rice seedlings. A Complete Randomized Design (CRD) consisted of 8 treatments with 5 replications was applied in this experiment. These included immersing of rice seeds in fish waste fertilizer with concentrations of $0.5 \%=$ $\mathrm{P} 1,1 \%=\mathrm{P} 2,1.5 \%=\mathrm{P} 3,2 \%=\mathrm{P} 4,2.5 \%=\mathrm{P} 5$ and $3 \%=\mathrm{P} 6$ with volume/volume ratio $(\mathrm{v} / \mathrm{v})$, prior to soaking. Rice seeds without immersion in this fertilizer $(\mathrm{C} 0)$ and those immersed in PGPR bacterial suspension only (C1) served as nil control and control treatments, respectively. The results showed that the application of $2.5 \%$ fish waste fertilizer produced the highest results, following measurement of parameters, including the percentage of germination $(88.18 \%)$, plant height $(28.78 \mathrm{~cm})$, and root length $(20,74$ $\mathrm{cm})$ on day 15 after sowing.

\section{INTRODUCTION}

\subsection{Research Background}

Rice (Oryza sativa L.) is a type of plant that is used as the main commodity by the government in increasing food production and self-sufficiency. According to Ref. [1], dry grain production which reached 54.60 million tons still did not meet the food needs of the Indonesian population which reached 252.17 million people with consumption levels reaching $132.98 \mathrm{~kg} / \mathrm{year}$. Therefore, increasing rice production is a top priority to address food shortages.

In Indonesia, rice production is still not sufficient for the food needs of the population [2], even rice production has decreased. The decline in rice production every year, which is thought to be due to the application of cultivation techniques and the application of fertilizers by farmers is not suitable. The decrease in production was also caused by a decrease in the area of rice fields. This is reinforced by a statement from Ref. [3] which states that there has been a decrease in the area of planted land from 7.75 million hectares (Ha) in 2013 to 7.1 million hectares in 2018. In addition to the decrease in planted area, the decrease in rainfall intensity is also a factor that causes a decrease in crop yields. Based on these data, efforts are needed to increase the production of rice fields to meet food needs. One system that can be applied is through planting with an organic farming system.

Currently, agricultural products are of particular concern to several developed and developing countries, including Indonesia. Many agribusiness entrepreneurs and farmers have started implementing organic farming systems, because they have a high market share, including rice plants. The requirements in the application of organic farming systems are the provision of nutrients or organic fertilizers. However, the use of both liquid and solid fertilizers has been widely carried out but is not optimal [4]. Organic fertilizers can be interpreted as the result of the decomposition of organic materials by microorganisms so that they can produce nutrient elements that are utilized by plants for their development and growth [5]..

One of the organic materials that can be used as fertilizer is fish waste. The use of fish waste as organic fertilizer is still rarely known by the public so many do not understand how to use it. The role of microorganisms in the process of making organic fertilizers is very useful because they can break down and degrade organic materials into simple nutrients for plant growth and development [6]. Based on the above mentioned, research was conducted on the use of organic fertilizer based on fish waste to increase the growth of Bali Red Rice. 


\subsection{Literature Review}

The use of microorganisms in agriculture has been widely used. The use of rhizobacteria belonging to the Plant Growth Promoting Rhizobacteria (PGPR) is a group of bacteria that live saprophytically in the rhizosphere or the root system [7]. Plant growth-promoting rhizobacteria or PGPR are very beneficial for plants because PGPR bacteria can produce the hormone IAA (Indole Acetic Acid). IAA hormone is an auxin phytohormone that is found in nature and can be divided into endogenous and exogenous IAA hormones [8]. Endogenous IAA hormone is a growth hormone produced by plants, while exogenous IAA hormone is a hormone produced by microorganisms that can stimulate root growth in plants that function in nutrient absorption. Root formation is stimulated by bacteria that produce the hormone IAA [9].

\subsection{Research Objective}

The objective of this study was to investigate the effect of liquid organic fertilizer made from fish waste on the growth of Bali red rice seedlings.

\section{MATERIALS AND METHODS}

\subsection{Bacterial Isolation}

Bacterial isolation was carried out by taking soil samples from the rhizosphere or plant root system in the rice fields of Samsam Village in Tabanan, Sempidi rice fields in Badung, and Biology Campus of Udayana University Bukit Jimbaran. Soil samples were transported to the Udayana University Biopesticide Laboratory for bacterial isolation.

\subsection{IAA Hormone Testing}

The IAA hormone test was carried out by inoculating the previously obtained bacteria into liquid media or nutrient broth (NB) and incubating them for 24-48 hours. The grown isolates were then transferred to a multi-level chamber and dripped with Salkowski reagent. Positive results will be indicated by a change in color to pink after incubation in the dark for 30 minutes. The darker pink color indicated a higher level of IAA produced [10].

\subsection{Protease Activity Test}

A proteolytic activity test was carried out by culturing bacterial isolates on 2\% SMA media (Skimmed Milk Agar) made with $2 \mathrm{~g}$ skimmed milk and $3 \mathrm{~g}$ Nutrient Agar then dissolved with distilled water to a final volume of $100 \mathrm{ml}$, then sterilized by autoclave at $121^{\circ} \mathrm{C}$ for 20 minutes. The previous bacterial isolates were cultured on 2\% SMA media and incubated for 24-48 hours at $35-37^{\circ} \mathrm{C}$. The presence of protease enzyme activity is indicated by the presence of a clear zone around the bacterial colony [11].

\subsection{Making Liquid Organic Fertilizer}

The production of liquid organic fertilizer which is then denoted as treatment $(\mathrm{P})$, first prepared $100 \mathrm{~g}$ of tilapia waste (meat, bones, and offal), $100 \mathrm{~g}$ of potatoes, and $100 \mathrm{~mL}$ of rice washing water waste, then added with distilled water until it reaches 1 liter and boiled for 30 minutes, then filtered. After cooled, $100 \mathrm{~mL}$ of PGPR bacterial suspension with the name JL2 was added which was isolated from Jatiluwih rice fields. and fermented for 2 weeks. Liquid organic fertilizer is ready for use [4].

\subsection{Seedling}

The seeding method is carried out on a tray with soil media. The seeds used are Balinese red rice seeds originating from Jatiluwih. First, the rice seeds were soaked for 24 hours using plain water. The seeds were soaked again in liquid organic fertilizer previously made for 6 hours with different concentrations of fish waste fertilizer such as $0.5 \%=\mathrm{P} 1,1 \%=$ $\mathrm{P} 2,1.5 \%=\mathrm{P} 3,2 \%=\mathrm{P} 4,2.5 \%=\mathrm{P} 5$ and $3 \%=\mathrm{P} 6$ using volume per volume $(\mathrm{v} / \mathrm{v})$ concentration with 5 replications each, and 2 control treatments, without soaking $(\mathrm{C} 0)$ and only soaking using PGPR bacterial isolate (C1). Then, the seeds are sown into soil media in trays for 15 days. Data were taken after 15 days after sowing, which included the percentage of germination, seedling height, number of leaves, and root length [4].

\subsection{Fertilizer Nutrient Content Test}

Nutrient parameters calculated include C-Organic content calculated using the Walkey-Black method, nitrogen $(\mathrm{N})$ content calculated using the Kjeldahl method, phosphorus (P), and potassium $(\mathrm{K})$ content calculated using the Spectrophotometric method [12].

\subsection{Observed Parameters}

The parameters observed and measured were the growth parameters of red rice plants which included the percentage of germination, seedling height, number of leaves, root length, and explained the physical condition of the seeds. The germination percentage of the seeds were calculated using the following formula:

(Number of germinated seeds)/(Total number of seeds) $x 100 \%$

\subsection{Data analysis}

The data obtained were analyzed quantitatively using analysis of variance ANOVA $(\mathrm{p}<0.05)$ and expressed as the average value. If significantly different data were obtained, then the test was continued with Duncan's multiple distance test to determine the differences between treatments.

\section{RESULT AND DISCUSSION}

\subsection{Bacteria Isolation}

A total of 16 bacterial isolates were purified and 5 were obtained from the root system of Sesbania sp. (Table 1).

\subsection{IAA Hormone Test}

The results of the capability of previously isolated bacterial species to produce IAA are shown in Table 2, obtained total of 9 out of 12 bacteria tested, were able to produce IAA hormone which was indicated by a color change of the samples (ranged from yellowish to pink). The darker the pink color produced the higher the level of IAA hormone produced [10]. 
Table 1. Bacterial Isolates from Various Sources

\begin{tabular}{|c|c|c|c|}
\hline Number & Plant rhizosphere & $\begin{array}{l}\text { Isolates } \\
\text { Name }\end{array}$ & Amount \\
\hline 1 & Piper caninum & $\begin{array}{l}\mathrm{PC} 1, \\
\mathrm{PC} 2\end{array}$ & 2 \\
\hline 2 & Turi (Sesbania sp.) & $\begin{array}{l}\text { TR1, } \\
\text { TR2, } \\
\text { TR3, } \\
\text { TR4, } \\
\text { TR5 }\end{array}$ & 5 \\
\hline 3 & $\begin{array}{l}\text { Merak (Caesalpinia } \\
\text { pulcherrima) }\end{array}$ & $\begin{array}{l}\text { MR1, } \\
\text { MR2 }\end{array}$ & 2 \\
\hline 4 & $\begin{array}{l}\text { Lamtoro (Leucaena } \\
\text { sp.) }\end{array}$ & $\begin{array}{l}\text { LM1, } \\
\text { LM2 }\end{array}$ & 2 \\
\hline 5 & $\begin{array}{l}\text { Paddy field of } \\
\text { Jatiluwih }\end{array}$ & JL1, JL2 & 2 \\
\hline 6 & $\begin{array}{l}\text { Paddy field of Samsam } \\
\text { (Tabanan) }\end{array}$ & $\begin{array}{l}\text { TBN1, } \\
\text { TBN2 }\end{array}$ & 2 \\
\hline 7 & $\begin{array}{l}\text { Paddy field of Sempidi } \\
\text { (Badung) }\end{array}$ & BDG1 & 1 \\
\hline
\end{tabular}

Table 2. IAA Hormone Results

\begin{tabular}{ccc}
\hline Number & Isolates Name & Positive/Negative \\
\hline 1 & PC1 & + \\
2 & MR1 & + \\
3 & BDG1 & - \\
4 & TR2 & - \\
5 & TBN1 & ++ \\
6 & TBN2 & - \\
7 & JL2 & ++ \\
8 & PC2 & + \\
9 & TR1 & + \\
10 & JL1 & + \\
11 & LM2 & + \\
12 & TR3 & + \\
\hline
\end{tabular}

Note: The double-positive sign (++) indicates a high IAA test result based on the level of color density produced after the test [10].

The results of the IAA hormone test showed that 9 out of 12 bacteria showed positive results. These bacteria can produce the hormone IAA which is the main hormone in regulating plant physiological activities. Naturally, Rhizobium bacteria will gather around the root hairs. These bacteria can loosen cell walls in plant roots and can increase root exudates which can provide additional nutrients to support the growth of rhizobium bacteria. Rhizobium bacteria that colonize the root hairs will convert the tryptophan compounds contained in the root exudate into IAA compounds [13].

\subsection{Protease Activity Test}

A total of 12 pure culture isolates were tested for protease activity, and 5 isolates showed positive results which were indicated by the formation of a clear zone around the bacterial colonies (Table 3).

Protease activity test results showed 5 of the 12 types of bacteria that showed positive results. Proteolytic bacteria can produce extracellular protease enzymes, which are enzymes that can break down proteins produced in cells, then sent out of cells [14]. Testing of proteolytic activity using SMA (Skimmed Milk Agar) selective media, where skimmed milk contains casein which can be used as an enzyme-substrate. Casein degradation is intended to see the activity of the protease enzyme [15]. In nature, proteins that are degraded by proteolytic microorganisms will form amino acids, which are then re-formed into $\mathrm{CO}_{2}, \mathrm{H}_{2} \mathrm{O}$, and ammonia $\left(\mathrm{NH}_{3}\right)$ which are released into the environment. Ammonia will be reformed back into ammonium and into nitrite and nitrate which can be utilized by plants in the process of growth and development [14].

\begin{tabular}{cccc}
\multicolumn{4}{c}{ Table 3. Protease Activity of Tested Isolates } \\
\hline \multirow{2}{*}{ Number } & $\begin{array}{c}\text { Isolates } \\
\text { Names }\end{array}$ & Positive & Negative \\
& PC1 & $\sqrt{ }$ & $\sqrt{ }$ \\
2 & MR1 & & \\
3 & BDG1 & $\sqrt{ }$ & \\
4 & TR2 & $\sqrt{ }$ & $\sqrt{ }$ \\
5 & TBN1 & & $\sqrt{ }$ \\
6 & TBN2 & & $\sqrt{ }$ \\
7 & JL2 & $\sqrt{ }$ & $\sqrt{ }$ \\
8 & PC2 & & \\
9 & TR1 & & $\sqrt{ }$ \\
10 & JL1 & $\sqrt{ }$ \\
11 & LM2 & & $\sqrt{ }$ \\
12 & TR3 & &
\end{tabular}

Note: Positive results were indicated by clear zone formation. Fertilizer Nutrient Content

The fertilizer nutrient content testing is shown in Table 4 . The results of the nutrient content test showed that there were several main ingredients of fertilizers such as phosphor $(231.18 \mathrm{mg} / \mathrm{L})$, potassium $(38.5 \mathrm{mg} / \mathrm{L})$, nitrogen $(0.06 \%)$, and C-Organic $(0.78 \%)$. Ref. [16] stated that fish waste contained $39.2 \mathrm{mg} / \mathrm{L}$ of $\mathrm{N}$ nutrients, $1.257 \mathrm{mg} / \mathrm{L}$ of $\mathrm{P}$ nutrients, and $<0.03 \mathrm{mg} / \mathrm{L}$ of $\mathrm{K}$ nutrients. Nitrogen nutrients are very important for plant growth, but if you look at Table 5, the fertilizer nutrient content test shows a low nitrogen content of $0.06 \%$, this can happen due to several factors such as the material content of the fertilizer, microbes that grow during the fermentation process, and duration of fermentation. In addition, there is also a nitrogen cycle factor that occurs during the fermentation process, where the fermentation process is carried out anaerobically which causes the nitrification process to be less than optimal, but on the contrary, the denitrification process increases [17]. The nutrient content of nitrogen $(\mathrm{N})$ in the liquid organic fertilizer of fish waste is obtained from the ammonification process, where this process breaks down amino acids and proteins into ammonia (NH3) which contains nitrogen compounds [18]. The phosphor (P) content in fertilizer comes from bone waste, where fish bones contain high calcium and phosphor. Fishbones contain valuable phosphorus and carbonates [19]. Then, the nutrient content of potassium $(\mathrm{K})$ in fertilizer comes from rice washing water and potatoes, according to Ref. [20], rice washing water contains potassium of $91.11 \mathrm{ppm}$ and potatoes themselves are a good source of potassium, where one potato contains potassium. 600 $\mathrm{mg}$ of potassium.

Growth parameters measured included germination rate, plant height, number of leaves, root length, and physical condition of the plant. Seed immersion treatments, which are presented in Table 6 , show a significant effect on the averages seed germination. There was a significant difference between PGPR immersion (85.0.9\%) and fertilizer with a concentration of $2.5 \%$ (88.18\%) compared to the control treatment (54.90\%). This shows that soaking the seeds using organic fertilizers and PGPR 
can increase the uniformity of seeds in germination. Ref. [21] stated that seed soaking treatment using organic fertilizer and PGPR is an attempt to increase seed viability so that it can accelerate root growth and produce seeds that grow in optimum conditions. Inside the seeds, there are food reserves and growth hormones that are immediately active when exposed to water, but if the food reserves and hormones are available in small quantities, then plant growth will also not be optimal [22]. Seed immersion treatment using organic fertilizers and PGPR can increase minerals or plant growth substances in the seeds so that plant growth can be maximized [23].

Table 4. Nutrient Content of the Liquid Organic Fertilizer Made of Fish Waste

\begin{tabular}{cccc}
\hline Number & Parameter & Unit & Result \\
\hline 1 & Phosphor $(\mathrm{P})$ & $\mathrm{mg} / \mathrm{L}$ & 231.18 \\
2 & Potassium $(\mathrm{K})$ & $\mathrm{mg} / \mathrm{L}$ & 38.5 \\
3 & C-Organic & $\%(\mathrm{~m} / \mathrm{v})$ & 0.78 \\
4 & Nitrogen $(\mathrm{N})$ & $\%(\mathrm{~m} / \mathrm{v})$ & 0.06 \\
\hline
\end{tabular}

\subsection{Percentage of Balinese Rice Seed Germination (Jatiluwih Red Rice)}

The percentage of seed germination falls between $54.9 \%$ to $88.18 \%$ (Table 5). Rice seeds previously treated with $2.5 \%$ fish waste fertilizer showed the highest rate of germination $(88.18 \%)$.

Table 5. Percentage of Seed Germination

\begin{tabular}{|c|c|}
\hline Treatments & $\begin{array}{c}\text { Seed Germination Average } \\
(\%)\end{array}$ \\
\hline $\mathrm{C0}:$ Control & $54.90 \% \pm 0.50 \mathrm{~b}$ \\
\hline C1 : Immersion with PGPR & $85.09 \% \pm 0.35 \mathrm{a}$ \\
\hline $\begin{array}{l}\text { P1 : Immersion with } 0.5 \% \text { fish } \\
\text { waste fertilizer }\end{array}$ & $80.37 \% \pm 0.39 \mathrm{a}$ \\
\hline $\begin{array}{l}\text { P2: Immersion with } 1 \% \text { fish } \\
\text { waste fertilizer }\end{array}$ & $85.29 \% \pm 0.35 \mathrm{a}$ \\
\hline $\begin{array}{l}\text { P3: Immersion with } 1.5 \% \text { fish } \\
\text { waste fertilizer }\end{array}$ & $82.05 \% \pm 0.38 \mathrm{a}$ \\
\hline $\begin{array}{l}\text { P4: Immersion with } 2 \% \text { fish } \\
\text { waste fertilizer }\end{array}$ & $87.50 \% \pm 0.33 \mathrm{a}$ \\
\hline $\begin{array}{l}\text { P5: Immersion with } 2.5 \% \text { fish } \\
\text { waste fertilizer }\end{array}$ & $88.18 \% \pm 0.32 \mathrm{a}$ \\
\hline $\begin{array}{l}\text { P6: Immersion with } 3 \% \text { fish } \\
\text { waste fertilizer }\end{array}$ & $82.35 \% \pm 0.38 \mathrm{a}$ \\
\hline
\end{tabular}

Note: Values in table $6 \pm$ standard deviation are the averages of 5 replications. Numbers followed by the same letter are not significant based on Duncan's multiple-spaced test at the $5 \%$ level $(\mathrm{P}>0.05)$.

\subsection{Balinese Rice Seedling Height (Jatiluwih Red Rice)}

Immersion of fish waste fertilizer did not show a significant effect at the level of $5 \%(\mathrm{P}<0.05)$ on the height of red rice seedlings (Table 6). The fertilizer immersion treatment with a concentration of $2.5 \%$ gave the highest average yield, which reached a height of $28.78 \mathrm{~cm}$.

The results of the calculation of the height of the red rice plant, which is presented in Table 6 , show insignificant results at the $5 \%$ level $(\mathrm{P}<0.05)$ for the height of the red rice plant, but the highest yield was shown by the seed soaking treatment using a fertilizer with a concentration of $2.5 \%$, which reached $28.78 \mathrm{~cm}$. This effect is based on the ability of the microorganisms contained in the organic fertilizers of fish waste to help absorb nutrients in the soil and produce growth hormones for the plants

16 Kusuma et al. themselves [6]. In the organic fertilizer of fish waste, some micro and macronutrients can improve the quality and growth of plants. In addition, microorganisms (PGPR) can produce phytohormones such as Auxins, Cytokinins, and Gibberellins so that plants look better [24]. Ref. [23] stated that giving plant growth substance by soaking seeds using organic fertilizer and PGPR can increase plant development and growth more optimally. Additional plant growth substance immersion in seeds can also increase stem growth, so that the resulting stems become longer and larger, due to the influence of plant growth substances which can increase the plant growth process [25].

Table 6. Average Seedling Height

\begin{tabular}{lc}
\hline Treatments & $\begin{array}{c}\text { Average Seedling } \\
\text { Height }(\mathrm{cm})\end{array}$ \\
\hline C0 : Control & $26.52 \pm 2.24 \mathrm{a}$ \\
C1 : Immersion with PGPR & $28.36 \pm 3.34 \mathrm{a}$ \\
P1: Immersion with 0.5\% fish waste fertilizer & $26.54 \pm 2.93 \mathrm{a}$ \\
P2: Immersion with 1\% fish waste fertilizer & $28.32 \pm 2.17 \mathrm{a}$ \\
P3: Immersion with 1.5\% fish waste fertilizer & $28.28 \pm 1.27 \mathrm{a}$ \\
P4: Immersion with 2\% fish waste fertilizer & $28.64 \pm 1.09 \mathrm{a}$ \\
P5: Immersion with 2.5\% fish waste fertilizer & $28.78 \pm 2.78 \mathrm{a}$ \\
P6: Immersion with 3\% fish waste fertilizer & $28.36 \pm 2.58 \mathrm{a}$ \\
\hline
\end{tabular}

Note: Values in Table $6 \pm$ standard deviation are the averages of 5 replications The averages height of the seedlings is not significant based on the $5 \%$ level $(\mathrm{P}<0.05)$.

\subsection{Number of Balinese Rice Leaves (Jatiluwih Red Rice)}

From the results of testing rice seeds with soaking treatment with fish waste fertilizer with different concentrations, it showed a significant effect at the $5 \%$ level $(\mathrm{P}>0.05)$, on the number of leaves of red rice seeds. The results of observations of the number of leaves on red rice seedlings presented in Table 7, showed that in PGPR immersion, fertilizer immersion with a concentration of $2 \%$ and $2.5 \%$ gave the highest average number of leaves reaching 2.8 strands.

Table 7. Average Number of Leaves

\begin{tabular}{|c|c|}
\hline Treatments & Average Number of Leaves \\
\hline C0: Control & $0.02 \pm 0.00 \mathrm{~b}$ \\
\hline $\mathrm{C} 1$ : Immersion with PGPR & $2.8 \pm 0.44 \mathrm{a}$ \\
\hline $\begin{array}{l}\text { P1 : Immersion with } 0.5 \% \text { fish waste } \\
\text { fertilizer }\end{array}$ & $2.0 \pm 0.00 \mathrm{~b}$ \\
\hline $\begin{array}{l}\text { P2: Immersion with } 1 \% \text { fish waste } \\
\text { fertilizer }\end{array}$ & $2.2 \pm 0.44 \mathrm{~b}$ \\
\hline $\begin{array}{l}\text { P3: Immersion with } 1.5 \% \text { fish waste } \\
\text { fertilizer }\end{array}$ & $2.2 \pm 0.44 \mathrm{~b}$ \\
\hline $\begin{array}{l}\text { P4: Immersion with } 2 \% \text { fish waste } \\
\text { fertilizer }\end{array}$ & $2.8 \pm 0.00 \mathrm{a}$ \\
\hline $\begin{array}{l}\text { P5: Immersion with } 2.5 \% \text { fish waste } \\
\text { fertilizer }\end{array}$ & $2.8 \pm 0.44 \mathrm{a}$ \\
\hline $\begin{array}{l}\text { P6: Immersion with } 3 \% \text { fish waste } \\
\text { fertilizer }\end{array}$ & $2.0 \pm 0.00 \mathrm{~b}$ \\
\hline
\end{tabular}
fertilizer

Note: Values in Table $8 \pm$ standard deviation are the averages of 5 replications. Numbers followed by the same letter are not significant based on Duncan's multiple-spaced test at the 5\% level (P > 0.05).

The results of observations of the number of leaves on red rice plants presented in Table 7, showed significant results at the $5 \%$ level $(\mathrm{P}>0.05)$, where the highest yield as indicated by seed soaking treatment using PGPR, fertilizer $2 \%$ and $2.5 \%$ which reached an average of 2.8 leaves. This can occur due to the 
influence of PGPR bacteria which can provide or facilitate the absorption of nutrients in the soil and produce phytohormones that trigger leaf growth. In addition to nutrients, the growth of the number of leaves can also be influenced by nitrogen nutrients obtained from soaking organic fertilizers [26]. According to Ref. [6], increasing leaf, stem, and root growth is one of the roles of nitrogen in fertilizers. The element nitrogen also has a role in the formation of leaf green matter (chlorophyll) which plays a very important role in the photosynthesis process [27].

\subsection{Balinese Rice Root Length (Jatiluwih Red Rice)}

The test results showed a significant effect at the 5\% level (P $>0.05)$, see where the rice seeds treated with fertilizer immersion had longer root sizes compared to seeds not treated with fertilizer immersion. The results of observations of root lengths of red rice seeds presented in Table 8, showed that immersion of fertilizer with a concentration of $3 \%$ gave the highest average root length reaching $21.12 \mathrm{~cm}$.

Table 8. Average Root Length

\begin{tabular}{lc}
\hline Treatments & $\begin{array}{c}\text { Average Root Length } \\
(\mathrm{cm})\end{array}$ \\
\hline C0 : Control & $14.88 \pm 3.41 \mathrm{c}$ \\
C1 : Immersion with PGPR & $19.08 \pm 1.24 \mathrm{~b}$ \\
P1: Immersion with 0.5\% fish waste & $20.32 \pm 2.86 \mathrm{c}$ \\
fertilizer & \\
P2: Immersion with 1\% fish waste & $20.76 \pm 2.79 \mathrm{a}$ \\
fertilizer & \\
P3: Immersion with 1.5\% fish waste & $19.28 \pm 1.99 \mathrm{~b}$ \\
fertilizer & \\
P4: Immersion with 2\% fish waste & $20.74 \pm 1.71 \mathrm{a}$ \\
fertilizer & \\
P5: Immersion with 2.5\% fish waste & $21.12 \pm 0.73 \mathrm{a}$ \\
fertilizer & \\
P6: Immersion with 3\% fish waste \\
fertilizer
\end{tabular}

Note: Values in Table $8 \pm$ standard deviation are the averages of 5 replications. Numbers followed by the same letter are not significant based on Duncan's multiple-spaced test at the 5\% level $(\mathrm{P}>0.05)$.

The results of the calculation of plant root length, which are presented in Table 8, also show a significant effect at the 5\% level ( $\mathrm{P}>0.05)$, with the highest yield indicated by the immersion treatment of fertilizer with a concentration of $3 \%$, which gives an average yield of length. the highest root that reaches $21.12 \mathrm{~cm}$. Ref. [26] stated that soaking seeds with hormones with the right concentration can increase the process of water absorption by seeds (imbibition) so that it can increase seed germination. Treatment by soaking the seeds before planting aims to accelerate the germination process so that it can accelerate the growth of root shoots [28]. The size and length of the roots are also determined by external factors, such as water content, nutrient content, and light intensity [25].

\subsection{Physical Condition of Bali Rice Plants (Jatiluwih Red Rice)}

No differences in the appearance of the rice seedlings following treatment with fertilizer and PGPR. Visually, those treated either with PGPR or fish waste fertilizer showed a better appearance.

The results of all observations and measurements made, when compared with the control, showed significantly different results at the $5 \%$ level $(\mathrm{P}>0.05)$, where the seed soaking treatment using organic fertilizer and PGPR showed better plant conditions, as seen from the plant height, number of leaves and root length, and plants look more fertile and have greener leaf colors. This is under [24] statement, which states that soaking seeds using organic fertilizers and PGPR before the planting phase, can provide additional nutrients and phytohormones to the seeds, to increase plant growth more optimally.

\section{CONCLUSION}

Seed immersion treatment using fish waste fertilizer gave a significant effect when compared to the control treatment. Soaking seeds with a fertilizer concentration of $2.5 \%$ showed the highest measurement results from the average percentage of germination $(88.18 \%)$, plant height $(28.78 \mathrm{~cm})$, number of leaves (2.8), and root length $(20.74 \mathrm{~cm})$.

\section{Acknowledgment}

The authors acknowledge the Head of the Biopesticide Laboratory, Faculty of Agriculture and the head of the Microbiology Laboratory, Biology Study Program, Faculty of Mathematics and Natural Science, Udayana University for the provision of laboratory equipment for this research. Our special thanks should also be addressed to the Directorate General for Higher Education, the Republic of Indonesia for its financial support on this project.

\section{REFERENCE}

[1] Badan Pusat Statistika Republik Indonesia. 2020. Berita Resmi Statistik "Luas Panen dan Produksi Padi di Indonesia 2019". BPS-RI. Jakarta

[2] Ariza, S. D. 2013. Analisis Pengaruh Ketersediaan Beras, Luas Panen Padi, Konsumsi Beras dan Harga Beras terhadap Ketahanan Pangan 38 Kabupaten/Kota Provinsi Jawa Timur. Jurnal Ekobis. 1(3) : 74-92

[3] Badan Pusat Statistika Republik Indonesia. 2019. Berita Resmi Statistik "Luas Panen dan Produksi Padi di Indonesia 2018". BPS-RI. Jakarta.

[4] Suriani, N. L., N. M. S. Pawanayoni and N. M. Suartini. 2015. Meningkatkan Produksi Bunga Potong Anthurium sp. melalui Pemanfaatan Pupuk Organik. Buletin Udayana Mengabdi. 15(2) : 19-23.

[5] Supartha, I. N. Y., G. Wijana dan G. M. Adnyana. 2012. Aplikasi Jenis Pupuk Organik pada Tanaman Padi Sistem Pertanian Organik. Jurnal Agroekoteknologi Tropika. 1(2) : 98-106.

[6] Diana, R. 2016. Respon Pertumbuhan Tanaman Cabai (Capsicum annum L.) Terhadap Pemberian Giberelin dan RPTT (Rizobakteri Pemacu Tumbuh Tanaman) Akar Putri Malu. Skripsi. Universitas Suryakancana. Cianjur.

[7] Elango, R., R. Parthasarathi and S. Megala. 2013. Field Level Studies on The Association of Plant Growth Promoting Rhizobacteria (PGPR) in Gloriosa superb L. Rhizosphere. Indian Streams Research Journal. 3(10) : 1-6.

[8] A'ini, Z. F. 2015. Isolasi Dan Identifikasi Bakteri Penghasil IAA (Indole-3-Acetid Acid) Dari Tanah Dan Air Di Situgunung, Sukabumi. Faktor Exacta. 6(3) : 231-240.

[9] Patil, L. 2011. Production of Indole Acetic Acid by Azotobacter sp. Rec Sec Sci Technol. 3(12) : 14-16.

[10] Sukmadewi, D. K. T., Suharjono dan S. Antonius. 2015. Uji Potensi Bakteri Penghasil Hormon IAA (Indole Acetic Acid) dari Tanah Rhizosfer Cengkeh (Syzigium aromatic L.). Jurnal Biotropika. 3(2) : 91-94.

[11] Kabense, R., E. L. Ginting, S. Wullur, N. J.Kawung, F. Losung and J. L. Tombokan. 2019. Screening of the Proteolytic Bacteria Symbiont with Algae Gracillaria sp. Jurnal Ilmiah PLATAX. 7(2) : 413-418.

[12] Susi, N., Surtinah dan M. Rizal. 2018. Pengujian Kandungan Unsur Hara Pupuk Organik Cair (POC) Limbah Kulit Nenas. Jurnal Ilmiah Pertanian. 14(2) : 46-51. 
[13] Glick, B. R. 2012. Plant Growth-Promoting Bacteria: Mechanisms and Applications. Scientifica. Hindawi.

[14] Hastuti, S. R., Febriani. S. A. N dan Putri. M. A. A. 2017. Identifikasi dan Penentuan Indeks Hidrolisis Protein Bakteri Proteolitik dari Tanah Mangrove di Margamulyo, Balikpapan. Proceeding Biology Education Conference. 14(1). 265-270.

[15] Harun, A., S. I. Muchlissin., A.H. Mukaromah., S. Darmawati dan S.N. Ethica. 2018. Isolasi Bakteri Penghasil Enzim Protease Staphylococcus hominis pada Oncom Merah Pasca Fermentasi 120 Jam. In Prosiding Seminar Nasional \& Internasional 1(1).

[16] Hapsari, $N$ dan T. Welasi. 2013. Pemanfaatan Limbah Ikan menjadi Pupuk organik. Jurnal Teknik Lingkungan. 2(1) : 1-6.

[17] Marsiningsih, N. W., A. N. G. Suwastika dan N. W. S. Sutari. 2014. Analisis Kualitas Larutan Mol (mikroorganisme lokal) Berbasis Ampas Tahu. Jurnal Agroekoteknologi Tropika (Journal of Tropical Agroecotechnology). 3(4) : 180-190.

[18] Yuliani, S. S., D. Useng dan M. Achmad. 2017. Analisis kandungan nitrogen tanah sawah menggunakan spektrometer. Jurnal Agritechno. 10(2) : 188-202.

[19] Malde MK, Bügel S, Kristensen M, Malde K, Graff IE, Pedersen JI. 2010. Calcium from salmon and cod bone is well absorbed in young healthy men: A double-blinded randomised crossover design. Nutr Metabolism 7: 61. DOI: 10.1186/1743-7075-7-61

[20] Mufid, N. 2018. Air Cucian Beras untuk Pembuatan Media Alternatif Pertumbuhan Microsporum sp. Doctoral dissertation. Universitas Muhammadiyah Semarang.

[21] Santoso, I., Sulistyani, dan Sudarsianto, 2014. Studi Perkecambahan Benih Kakao Melalui Metode Perendaman. Pusat Penelitian Kopi dan Kakao Indonesia, Jember.

[22] Silvia, P dan H. Sinay. 2014. Pengaruh Konsentrasi Giberelin dan Lama Perendaman Terhadap Perkecambahan Biji Sirsak (Anonna muricata L.). Jurnal Biopendix. 1(1) : 73-79.

[23] Fahmi, Z. I. 2014. Kajian Pengaruh Auksin Terhadap Perkecambahan Benih dan Pertumbuhan Tanaman. http://ditjenbunpertanian.go.id. (Diakses 30 Agustus 2016).

[24] Kania, S. R dan M. D. Maghfoer. 2018. Pengaruh Dosis Pupuk Kandang Kambing dan waktu Aplikasi PGPR terhadap Pertumbuhan Bawang Merah (Allium ascaloniucum L.). Jurnal Produksi Tanaman. 6(3) : 407-414.

[25] Septari, Y dan N. Nelvia. 2013. Pengaruh Pemberian Beberapa Jenis Ekstrak Tanaman sebagai ZPT dan Rasio Amelioran terhadap Pertumbuhan dan Produksi Padi Varietas Inpari 12 di Lahan Gambut. Diss. Riau University.

[26] Agustina, T dan M. Syamsiah. 2018. Aplikasi Lama Perendaman Benih dengan Mol (Mikroorganisme Lokal) dari Akar Putri Malu dalam Memacu Pertumbuhan Bibit Padi Pandanwangi. Journal of Agroscience. 8(1): 1-18.

[27] Mastur, M., S. Syararuddin dan M. Syakir. 2015. Peran Dan Pengelolaan Hara Nitrogen Pada Tanaman Tebu Untuk Peningkatan Produktivitas Tebu. Perspektif: Review Penelitian Tanaman Industri. 14(2), 73-86.

[28] Susanti, E. 2014. Petunjuk Praktikum Biokimia. Jurusan Kimia FMIPA UM. Malang. 